\title{
A gender perspective on entrepreneurial leadership: female leaders in Kazakhstan
}

Article

Accepted Version

Kakabadse, N. K., Tatli, A., Nicolopoulou, K., Tankibayeva, A. and Mouraviev, N. (2018) A gender perspective on entrepreneurial leadership: female leaders in Kazakhstan. European Management Review, 15 (2). pp. 155-170. ISSN 1740-4762 doi: https://doi.org/10.1111/emre.12125 Available at https://centaur.reading.ac.uk/72469/

It is advisable to refer to the publisher's version if you intend to cite from the work. See Guidance on citing.

To link to this article DOI: http://dx.doi.org/10.1111/emre.12125

Publisher: Wiley

All outputs in CentAUR are protected by Intellectual Property Rights law, including copyright law. Copyright and IPR is retained by the creators or other copyright holders. Terms and conditions for use of this material are defined in the End User Agreement.

\section{www.reading.ac.uk/centaur}

\section{CentAUR}

Central Archive at the University of Reading 
Reading's research outputs online 


\author{
Dr Nada K. Kakabadse \\ Professor of Policy, Governance and Ethics \\ Henley Business School \\ University of Reading \\ Henley-on-Thames \\ Oxfordshire RG9 3AU, United Kingdom \\ Phone: +44(0)1491 418786 \\ E-mail: n.kakabadse@henley.ac.uk
}

\author{
Ahu Tatli, PhD \\ Professor International Human Resource Management \\ School of Business and Management \\ Queen Mary, University of London \\ E1 4NS, London, UK \\ Phone: +44(0)20 78822698 \\ E-mail: a.tatli@qmul.ac.uk \\ Katerina Nicolopoulou, PhD \\ Senior Lecturer \\ Hunter Centre for Entrepreneurship \\ Strathclyde Business School \\ University of Strathclyde \\ E-mail: Katerina.nicolopoulou@strath.ac.uk
}

\author{
Aliya Tankibayeva \\ Lecturer \\ Department of Public Administration \\ KIMEP University \\ 4 Abay Ave, \#306 \\ Almaty, 050010 Kazakhstan \\ E-mail:aliyat@kimep.kz \\ Nikolai Mouraviev, PhD \\ Senior Lecturer in Business and Management \\ Dundee Business School \\ University of Abertay Dundee \\ 40 Bell St \\ Dundee, Scotland DD1 1HG, United Kingdom \\ Phone: +44 (0)1382 308362 \\ E-mail:n.mouraviev@abertay.ac.uk
}




\title{
A Gender Perspective on Entrepreneuril Leadership: Female Leaders in Kazakhstan
}

\begin{abstract}
The paper proposes a conceptual model to understand female entrepreneurial leadership through an exploration of the perceptions and experiences of women entrepreneurs within their leadership roles. The paper addresses an existing knowledge gap on entrepreneurial leadership by bringing together three key constructs of gender, leadership and entrepreneurship. We apply Stewart's (1982) model of role Demands-Constraints-Choices (DCC) to women entrepreneurs in Kazakhstan in order to understand their perceptions of the demands, constraints and choices they experience within their leadership roles. The results of in-depth interviews with women entrepreneurs present deeper conceptualisation of their leadership enactment as a co-developing, co-constructed relational activity between leaders and others in their wider business environments and context.
\end{abstract}

Keywords: Entrepreneurial leadership, gender, Kazakhstan, women entrepreneurs

\section{Introduction}

This paper explores how women leaders perceive and experience leadership demands, constraints and choices within entrepreneurial settings in the context of Kazakhstan. Although there is a widespread recognition of the importance of researching women in entrepreneurship, the nature of women's entrepreneurial effectiveness and leadership continues to be insufficiently researched (James, 2012). Furthermore, exploring the nexus of gender, leadership and entrepreneurship requires attention to the contexts within which women entrepreneurial leaders operate. We agree with Tlaiss (2013), that a conceptual framework that recognises the role played by the interaction between macro factors (national, cultural and societal characteristics and norms), meso factors (organisational, institutional), and micro factors (individual characteristics) is necessary to support a situated analysis which adopts a partially emic approach (see Tatli and Ozbilgin, 2012, for a discussion of the context specificity of the explanatory power of concepts and data). Tlaiss (2013) 
talks of 'gendered societies' as significant boundary-setting contexts for the development of entrepreneurship. Various studies conducted in the context of developing countries/transition economies (e.g. India: Datta and Gailey, 2012; Pakistan: Shabir and Di Gregorio, 1996; Lebanon: Jamali, 2009; S. Africa: Scott et al, 2012; Jordan: Al Dajani and Marlow, 2010; UAE: Tlaiss, 2013; Ghana: Dsizi, 2009; Lithuania and Ukraine: Aidis et al, 2007; Russia: Izyumov and Razumnova, 2000 ) concur that there are marked differences between the experiences of men and women entrepreneurs because of the differential availability of opportunities and contextual challenges (see also Foss (2010) and Ahl (2006) on entrepreneurship and doing gender). Aidis et al (2007), for example, highlight that, overall, in countries covered by the GEM studies reports, men have twice as many chances of becoming entrepreneurs than women, but women have more chances of pursuing 'social and economic missions' (Jennings and Brush, 2013). Potential contextbound/macro-level constraints in developing countries/transition economies also include institutional voids, unfavourable legal frameworks and embedded norms (such as patriarchy, religion and male dependency) (Mair and Lanuza, 2009; Jamali, 2009; Tlaiss, 2013), whilst several related challenges are often, counter-acted in practice by individual characteristics (eg: passion, determination, self-confidence; perseverance; ambition) that women entrepreneurs exhibit in order to survive and thrive (Jamali, 2009). To-date, we are still lacking substantive in-depth evidence on entrepreneurial women in developing countries/transition economies, who manifest an elite disposition, and are driven by innovation and opportunity (Nicolopoulou et al, 2016), as the main focus of the literature is on female entrepreneurship that is community-based or done through disadvantaged groups. Although, the literature has identified a number of commonalities between women entrepreneurs, (e.g. risk aversion, inability to access substantive finances; lack of motivation, education, desire to start a business, capacity to access support for decision-making and to employ networks effectively - see Ahl [2006)]. In this context, research on female entrepreneurship in developing countries/transition economies could offer important insights to this body of literature by bringing the 'context' as an important dimension of analysis.

The literature often defines an entrepreneur as actively engaging one's own vision, skills and abilities with the context whereby he or she exercises opportunities for value creation (Bjerke \& Rämö, 2011). However, the literature lacks agreement regarding the ways in which women enact such engagement and how such engagement materialises (Kobia \& Sikalieh, 2010). This article 
aligns with those perspectives that place entrepreneurial leadership within a more broadly defined process of social construction, which acknowledges the importance of context-based interactions (Hughes et al., 2012).

Furthermore, this study is set against a backdrop of debate about distinctive properties that women bring to leadership in organisations (Eagly \& Carli, 2007). A relatively large proportion of the literature highlights the importance of entrepreneurs' cognitions as determinants of entrepreneurial actions and leadership (Baron, 1998; Pech \& Cameron, 2006). In keeping with this line of thinking many studies emphasise that entrepreneurs have a set of cognitions in relation to growth and development different from 'non-entrepreneurs' (Pech \& Cameron, 2006). However, what remains underexplored are the perceptions and experiences of leadership, which inform the cognitions of entrepreneurial leadership (Bjerke and Rämöm, 2011). Jensen and Luthans (2006) referred to this as a gap in knowledge of both leadership and entrepreneurship. The present study aims to bridge this gap by exploring the leadership roles' demands, constraints and choices as perceived and experienced by women who lead entrepreneurial organisations. As such our research adopts reflexive and practical focus on the lived experience, as 'experience is what explains our grasp of the concepts of objects' and reality (Campbell, 2002: 137). For example, leadership experience facilitates the individual's internalisation of the leadership image and leader's role, which in turn impacts her/his motivation to continue in the leadership role in the future as well as reinforcing the self-efficacy in leading (Erikson, 1959; Bandura, 1986; Kotter, 1988). Thus, our focus in this paper is on the experiences and perceptions of leadership, and our research question is: How do women entrepreneurs perceive and experience leadership roles in the context of Kazakhstan?

The article begins with a review of the extant literature on female entrepreneurial leadership. This is followed by a discussion of Stewart's (1982) Demands-Constraints-Choices (DCC) model. The article then elucidates the entrepreneurial context in Kazakhstan and subsequently delineates the study's methodology. After that the findings drawn from the interview data are presented using the DCC framework. The final section offers a discussion of the findings and key conclusions.

\section{Female Entrepreneurial Leadership Framework}


In this article entrepreneurship is conceptualised as "a context-dependent social process through which individuals and teams create wealth by bringing together unique packages of resources to exploit marketplace opportunities" (Ireland et al., 2001: 51). Schumpeter (1934) defined the role of an entrepreneur as another form of individual leadership, whilst entrepreneurial leadership is conceptualised as a distinctive style of leadership that can be present in an organisation of any size, type, level of maturity, industry or culture (Renko et al., 2015). Entrepreneurial leadership entails "influencing and directing the performance of group members towards the achievement of organisational goals that involve recognising and exploring entrepreneurial opportunities" (Renko et al., 2015: 55). The distinguishing features of entrepreneurial leadership style are their unique perception and action, namely the focus on entrepreneurial goals (Shane and Venkataraman, 2000), recognition of opportunity, the possibility to innovate rather than imitate in the production and delivery of goods or services (Gaglio, 2004) and exploiting new opportunities in terms of activities and investments to increase returns (Choi and Shepard, 2004). Entrepreneurial leadership also incorporates gender because perception and actions, which are key constructs for understanding entrepreneurial leadership, are often gender biased (Hargittai and Shafer, 2006; Kennedy et al., 2003).

\section{Entrepreneurs as leaders and women as entrepreneurial leaders}

The significance of leadership in entrepreneurial settings is elucidated in the literature (e.g., Ensley and Pearce, 2001). Also, the literature highlights founders' managerial competencies (Chandler \& Hanks, 1994), founders' ability to communicate vision to employees (Baum et al., 1998), founders' role in establishing organisational culture (Schein, 1983), interactions to external stakeholders (Ehrlich et al., 1994) and leadership implications for the overall firm's performance (Daily \& Dalton, 1993). Although some researchers paid attention to the interplay between entrepreneurship and leadership, such work constitutes only a marginal proportion of the scholarship in these two fields of study (Cogliser \& Brigham, 2004; Jensen \& Luthans, 2006).

Lack of attention to the cross-section of entrepreneurship and leadership has influenced how gender is studied and framed in entrepreneurship research. Scholars have developed arguments about gender and entrepreneurship from the perspective of entrepreneurial identity, often depicting womanhood and entrepreneurship as conflicting discourses (Bennett \& Dann, 2000; Lewis, 2006; 
Wee \& Brooks, 2012). Garcia and Welter (2011) argue that we typically consider characteristics that pertain to successful entrepreneurship to be 'male', rather than 'female' (see also Shinnar et al., 2012 on discourses of gender and entrepreneurial intentions, and Davis \& Shaver, 2012, on discourse of gender and growth potential). However, as Bruni et al. (2004: 407) eloquently put "alternative forms of entrepreneurship exist in the same way as different forms of gender". In that context, Hughes et al. (2012) urge for changing the direction and epistemological positioning of research in order to build a deeper understanding of the interaction of the context with the individual, within a framework of gendered perspectives. As such, contextual approaches by demonstrating the geographical and historical situatedness of gender, may allow us to overcome the universalised gender discourses, such as the one on womanhood and entrepreneurship (Özbilgin et al., 2011). Parallel to that, the call for a social constructionist approach to conceptualise leadership (Leitch et al., 2013) highlights a converging pathway in appreciating the role of the context in the analysis of female entrepreneurial leadership.

A body of literature emphasises gender differences in a transformational leadership style. For example, researchers (Bass, 1999; Zhu et al., 2011) emphasise the importance of transformational leadership in creating effective and sustainable organisations and in contributing towards innovative management and leadership practices (Matzler et al., 2008), which correspond well to two entrepreneurial leadership attributes: innovation and proactiveness (Thornberry, 2006). Furthermore, researchers argued that women are particularly effective in people development, role modelling and clearly defining and communicating mutual expectations, rewards and responsibilities (Bass, 1990; Eagly et al., 2003). Other empirical research emphasise the connections between female leadership and positive organisational climate (Helgesen, 1995; Moore et al., 2011), teamwork (Gilligan, 1982), innovation and creativity (Idris, 2009) as well as continuous learning and collaboration (Rosener, 1990). It is argued that women are effective in enhancing one's own and participants' self-worth (Babalola, 2009; Rosener, 1990); practicing interpersonal sensitivity (Eagly \& Johannesen-Schmidt, 2001); and establishing trust and sharing knowledge (Moore et al., 2011; Rosener, 1990). The research further conceptualises women's leadership as a relational practice that challenges women to engage in a range of meaningful behaviours that result in relating the entrepreneur's vision to the tasks, skills, time, place, family responsibilities, available resources and all range of personal and contextual properties for the 
benefit of the enterprise, its participants and the wider community (Pless, 2011).

A common characteristic of women entrepreneurs and women leaders is that both tend to adopt a flexible pattern of work to accommodate family commitments (Kirkwood \& Tootell, 2008; LeeGosselin \& Grise, 1990). Essential elements in order to maintain this flexibility are the levers of support that an entrepreneur can have, such as a co-entrepreneur inside the business (e.g., a family member), as well as networks around the business that can provide support by creating and fostering social capital (Eddleston \& Powell, 2012). However, further research is needed to highlight ways in which gender relations are socially constructed in line with geographical and historical specificities of the very context they are borne out.

\section{Female leadership behaviour in entrepreneurial firms}

There are three research streams on determinants of female leadership behaviour: a) gendered nature of leadership roles; b) individual determinants of leadership behaviour and c) lack of models that may explain how individuals enact leadership roles. The stream of literature that addresses the gendered nature of leadership roles provides evidence for differences in leadership behaviours as determined by a culturally constructed expectation around women's behaviours and attitudes (Bass, 1990; Eagly \& Carli, 2007). This literature shows that gender differences have been institutionalised in organisations so that structures and routines impose role expectations to women differently compared to men (Eagly \& Carli, 2007). Most prominently, this body of work emphasises the universal relevance of gender differences in interpersonal behaviour, whilst differences in respect to other types of behaviours are responsive to national culture and other contextual influences (House et al., 2004; van Emmerik et al., 2008). Yet, individual women leaders and entrepreneurs do act both in accordance as well as counter to gender role expectations (Phillips \& Knowles, 2012). Therefore, such universalised approaches are limited in explaining how gendered leadership effects occur.

The second literature stream addresses the individual determinants of leadership behaviour and considers a range of personality traits, skills and competence, attitudes and motivations to be drivers of women's leadership behaviours (Kolb, 1999). Among determinants of entrepreneurs' behaviour the individual level factors are viewed as a main enabling force for entrepreneurship 
(Jensen \& Luthans, 2006). Although this literature strand informs us about individuals' properties that can contribute to their leadership role, there is little research that explains how individuals make themselves effective. Furthermore, this approach overlooks the role of context in generating the perceptions of effective leadership and an effective leader. As Mirchandani (1999) argues, introduction of gender as an integral determinant of leadership and entrepreneurship is particularly useful in recognising that these phenomena cannot be fully understood through individual-level factors.

The third literature stream addresses the lack of models that explain how individuals enact leadership roles. Studies show that individuals cannot enact leadership roles without reciprocity of other actors involved in the situation and without supportive contextual structures (Boal \& Hooijberg, 2000; Osborn et al., 2002). The central issue in this strand of literature, which remains insufficiently explored, is how and why individuals interact effectively with the context in enacting leadership in entrepreneurial activity (Mumford, 1986). Yet, literatures on both leadership and entrepreneurship emphasised the impact of cognitive processes that individuals develop about their roles and highlighted the importance of the context in shaping role-holder behaviours (Katz \& Sheperd, 2003). The concept of role can be described as the summation of the requirements with which the systems confront an individual member. Stewart (1982a) explained that the choices made within a role are affected by the demands and constraints that individuals experience. Ultimately, the personal views regarding the challenges encountered form the perceptions, and the orientation of those with whom they interact play an important role in determining the discretionary nature of their role. The degree of discretion within a specific role is therefore driven by the incumbents' ability to influence the boundaries, responsibilities and accountabilities of their role (Bowman and Kakabadse, 1997). Leadership perception is complex and multi-dimensional in nature including attitudinal dimensions (content, structure and function) and wider social context, which in turn has profound effects on a leader's judgment of her/his social world (Olson \& Zanna, 1993; Lee et al., 2015) as well as conceptualisation of the leadership role. Individuals base their choices on their perceptions of role-holder capabilities in certain roles and the latitude of discretional choices available for the role in the specific context (Kakabadse et al., 2009). Researchers further explore the sources of role discretion and find that all levels of personal and contextual factors determine behaviour choices (Kakabadse and Kakabadse, 2005). However, a 
general lack of integrative models that address leadership effectiveness, particularly for entrepreneurs, remains in regard to the complex interactions of contextual and individual determinants. This paper draws on Stewart's (1982) managerial role model as an integrative framework through which women's leadership in entrepreneurial settings can be conceptualised and studied.

\section{Stewart's role demands-constraints-choices (DCC) model}

Stewart (1982) explores individual behaviour in a manager's role as the behavioural choices that a manager exercises in carrying out the functions of his/her position. These choices are either discretional or prescribed and are determined by the manager's perception of role demands and role constraints. Demands are the minimum core of required duties, activities and responsibilities, which the manager must exercise within the role. Constraints are factors internal and external to the job that limit what the role-holder can do. The model suggests that role constraints in interaction with role demands both limit and provide opportunities for choices. Choices are behaviours that the role-holder can embrace or not. Role behaviour reflects what the individual does in response to the messages she or he perceives and in response to their own perception of the job (Levinson, 1966). The expectations of the role create both demands and constraints for the individual role-holder, whilst role behaviour provides the role set with information about the extent of compliance with expectations. According to Stewart (1982), it is the relevance of choices that the role-holder exercises in the situation at hand that determines leadership effectiveness. Stewart (1982) describes these choices as (1) what aspects of the job the manager chooses to emphasise in terms of time, effort and commitment of resources; (2) how and what tasks are delegated; and (3) how the manager handles his/her job boundaries. The DCC model captures all varieties of micro-, meso- and macro-demands and constraints that leaders experience in their leadership role (Stewart, 1982; Kroeck, 2003; Lowe, 2003). The model also highlights the importance of contextual awareness to leadership effectiveness (den Hartog, 2003).

\section{The Entrepreneurial Context in Kazakhstan}

Since 1991, Kazakhstani policy-makers embraced entrepreneurship as a driving force for reforms and advancement of their economy. In Kazakhstan, the government efforts to ensure sustainable economic development focuses on three areas: taking advantage of the nation's oil reserves and 
other natural resources; changing the economy's structure that rested on oil sales, largely inefficient agriculture and high dependence on imported goods; and developing entrepreneurship (Bhuiyan \& Amagoh, 2011). This was reflected in the strategic plan for social and economic development entitled Kazakhstan 2030 (Smirnova et al., 2012). The government views entrepreneurship as contributor to the overall business and economic sustainability, which is increasingly becoming Kazakhstan's main focus.

Creating infrastructure support for entrepreneurship played an important role in Kazakhstan's transition to a market economy. Whilst in the Soviet Union entrepreneurship was an illegal activity found in a shadow economy, the small-scale legal entrepreneurial activities were still observed in agriculture. Since 1987 the government began to loosen its strict laws, thus gradually allowing private enterprise. Teal et al. (2011) argue that one should view development of entrepreneurship in conjunction with infrastructure challenges (legal, technological, institutional and financial) as well as with socio-cultural beliefs. Typically, entrepreneurial preferences seemed to focus on either starting a business (usually a trade-based, non-franchise activity) or joining the family business (Teal et al., 2011). In Kazakhstan, the development of infrastructure for entrepreneurship in the 1990s was slow and often ineffective, manifesting itself in rigid, although poorly designed procedures for business registration, getting a business permit or a license. Legal registration of a new business was (and still is) bureaucratic and lengthy (i.e., it could take months), the institutional environment for starting a small business remains underdeveloped and unfriendly. Taxation remains a concern to entrepreneurs because of the possibility of multiple and lengthy audits that often are associated with extortion and/or disruption of business. The study of personal, environmental and performance variables in the 1990s in entrepreneurial firms concluded that the challenges of the context had an overall negative influence on personal entrepreneurial characteristics as well as performance and outcomes (Ibrayeva, 1999). However, personal efficacy could play an important role in positively influencing them (Ibrayeva, 1999).

Entrepreneurs are also influenced by the popular perception of a woman's role in society. Whilst one should not disregard modern influences on the nation's development, more traditional views of the woman's role prevail (i.e., woman as the caretaker of her family, both immediate and extended). Women's entrepreneurial activities are perceived by many as a distraction from family 
responsibilities. Some extreme views suggest that women managers should pay to their family if they engage in a leadership role. Whilst the Soviet government had for a long time attempted to change the woman's role from family orientation to work orientation, in modern-day Kazakhstan traditional perceptions of the woman's role remain strong and largely unchallenged.

Notwithstanding the widespread perception of a woman as a family caretaker, literature suggests that women in Kazakhstan have been effective in starting and running small businesses that involve family connections and family members. Werner (2003) provided an insightful understanding of the role of women towards building small-scale enterprises in Kazakhstan. Her findings show that women's business activity in Kazakhstan is located within a complex matrix of societal and family relationships, which provide different ways of support including manual, financial and transactional (Werner, 2003). The existence of such formal and informal market structures positions nations such as Kazakhstan at an advantage from the perspective of the favourable cultural climate for developing entrepreneurship (Hubner, 2009).

Considering that much of the literature on leadership and on women in leadership and entrepreneurship roles comes from the developed economies and in particularly Anglo-American context that assumes a stable and liberal institutional order (Lyne de Ver, 2008), it is important to explore the understanding of these roles in developing economies where challenges facing women's entrepreneurial leadership may be different. This is supported by the notion that societies vary in their ability to create and sustain entrepreneurial activity due to their cultures (Kreiser et al., 2010). Drawing on the historical, cultural and institutional influences that inform the choices, demands and constraints as perceived and experienced by women who lead entrepreneurial organisations, this paper highlights the interplay between gender, entrepreneurship and leadership in Kazakhstan.

\section{Methodology}

The methodological approach of this study is informed by a social constructionist ontology and interpretive epistemology (Fairhurst, 2009). The authors' understanding of entrepreneurial leadership as a gendered phenomenon is based on the premise that women entrepreneurial leaders' perceptions and experiences are socially constructed through contextually generated choices and 
constraints (see Bourne and Calás, 2013). In order to collect rich evidence into the perceptions and experiences of leadership in entrepreneurial settings, we have drawn a purposive snowball sample of 18 female senior managers from various organisations in Kazakhstan (Table 1). Although the method of snowballing is fundamentally a type of purposive sampling where existing participants recruit future subjects from amongst their acquaintances (Heckathorn, 1997; Browne, 2005), the formation of the sample was driven by the main research question: How do women entrepreneurs perceive and experience leadership roles? At the time of the study design in 2013, women contributed 40 per cent of Kazakhstan's GDP, accounted for 52 per cent of those engaged in small and medium-size enterprises (SMEs), make up 66 per cent of all individual entrepreneurs and occupied 28 seats in Kazakhstan's 154-seat two-chamber Parliament (World Bank, 2013).

Through our professional contacts with Association of Kazakhstan Entrepreneurs (KAZKA) as well as our personal networks we identified a diverse sample of organisations that have characteristics of an entrepreneurial organisation (Timmons, 1994; Kuratko \& Hodgetts, 2009) and had women in leadership positions. However, we did not equate all business activity as entrepreneurial activity. Furthermore, whilst selecting respondents, we looked for the evidence that they are active in their leadership roles and perceive themselves as entrepreneurs, whether they lead in the context of a solo owner, start-up or as part of a team inside a large and/or government organisation trying to improve through innovation, which is dependent on creating value from ideas and ability to understand and manage the innovation process (Drucker, 1985; Gaglio, 2004). Particular focus was given to the understanding of the women's entrepreneurial ability to create and implement their ideas in their leadership roles within their context. Namely, of particular interest was whether women are able to act entrepreneurially or, as French economist J.B. Say, who coined the term 'entrepreneur', noted in 1803, whether women can shift 'economic resources out of an area of lower and into an area of higher productivity and greater yield' (Drucker, 1985: 21). Selection criteria for participants specified that a woman must have at least three years of experience in senior management roles (e.g. CEO, owner, director, general manager, managing partner or equivalent). To answer the research question, we drew solely from a sample of women who exercise leadership in entrepreneurial settings. Table 1 provides a descriptor of the sample for this study. 


\section{INSERT TABLE 1 ABOUT HERE}

We developed an interview protocol based on literature review and on our experience of similar studies in different contexts. The protocol was tested by two highly experienced women entrepreneurs in leadership roles. We subsequently fine-tuned our thematic-based questions. Although we had DCC model as a framework, this was not obvious to the study participants during questioning. Participants were asked talk about and reflect on their lived experience and related activities. For example, rather than asking study participants to reflect on their perceived role demands (i.e. activities that must be done), we asked them to reflect on the nature of their role responsibilities and accountability. Similarly, we explored role constraints (i.e. influences that limit what a job holder can do) by asking interviewees to reflect on challenges they face in enacting their role. Similarly, choices (i.e. activities that can be done given the respective demands and constraints) were explored by asking participants to reflect on activities they undertake, why they have undertaken these particular activities and how they have gone about selecting these activities. As participants expressed desire not to be recorded by means of any electronic device, data were recorded manually. Our participants objection to voice recording was not surprising for us as this was a cultural phenomenon we encountered in other contexts, such as Middle East and China. In addition, we agree with Clark (2006: 421) that, 'the tape recorder instantaneously transforms an informal and perhaps more informative interview into a formal platform for political statements'.

Without recording using electronic devices, all interviews have rested on trust between the interviewee and interviewer.

Interviews were conducted during late 2013 and early 2014. Although manual data recording was time-consuming and at times physically tiring experience, it allowed establishing a comfortable and trustworthy environment. Besides, participants seemed to be comfortable with the unhurried flow of the interview and took pauses for thinking over answers and even guiding researcher's note-taking. Each interview lasted approximately one and a half hour. As two of the researchers are native to the participants' culture and are bilingual speakers, it was not difficult to capture the meaning of the leadership roles as expressed by the participants, allowing effective probing, clarification and feedback. The issue of translation has appeared important during the 
coding and categorisation process and interview notes were translated to English and re-typed by bilingual researchers who were able to preserve the original meaning of interviewees' comments.

Semi-structured, in-depth interviews have been selected as the main data collection method due to the potential of collecting information-rich data narratives (Patton, 1987). House and Solberg (2004) have identified rich narratives in the tradition of social construction to be one of the most effective ways to understand dynamics involved in high echelon positions. Data were analysed thematically within the DCC framework, which allowed us to identify frequent, dominant or significant themes that emerge from the raw data (Saldana, 2009; Guest et al., 2012). The goal of this analysis was to find regularities and common patterns of demands, constraints and choices among lived experiences of the participants, even if they belong to different industries and have diverse professional backgrounds. The process involved data coding, categorisation, display of representative data, verification and drawing conclusions (Miles \& Huberman, 1994; Thomas, 2006), whilst interviewees were assigned nicknames in order to ensure anonymity. Data analysis is an iterative process that requires enquirers to immerse into data, code the interview transcript separately and then agree on the most appropriate codes (Bernard \& Ryan, 2010) when there are discrepancies. Data coding was carried out in three stages. At the first stage data were organised by themes. Themes that recurred in the interviews were located and coded through a meticulous reading of the transcripts by the research team. This manner of coding enabled categories emerge from within the text, rather than imposing them (Charmaz, 1995). In the second stage, or level two coding (Strauss, 1987) or axial coding (Hutchinson, 1988), the axes of the themes were analysed in order to construct the broader categories. In the final stage three, the broader categories were examined within the theoretical framework-the DCC model-according to the content that was particularly rich and/or theoretically interesting to the researchers. Then the DCC model was used as a framework (i.e. high level thematic codes) to organise the lower level codes. The basic reliability check involved an analysis of whether the codes match the reality of participants' experience. Thus, the core chosen categories were the three categories of the DCC model - role demands, role constraints and choices.

\section{Findings and Analysis}

Our analysis highlights the relevance of role demands, role constraints and role choices to the 
leadership roles as experienced by women entrepreneurs in Kazakhstan. Furthermore, in enactment of leadership by women entrepreneurs, these three dimensions are interlinked in dynamic and interdependent ways.

\section{Role demands}

The participants emphasised role demands as essential factors for leadership effectiveness. The most essential role demand was a need to deliver results toward goal achievement:

"I see my main role demands as to be able to deliver results - to deadlines and as stipulated by organisational goals." (Participant B)

Another role demand that women highlighted as key for leadership roles was the ability to make sense of complex environments. This ability enables leaders to create a plausible explanation of the unknown reality and suggests ways of assigning manageable structures to such a reality for organisational actors in general and entrepreneurs specifically (Lord \& Hall, 2005; Mumford et al., 2007). The need to make sense of often unstructured realities and demands of the dynamic business environment is particularly acute in contextual settings that are characterised by socio-economic transformation as in the case of Kazakhstan.

A significant role demand that women perceive as a driving force to develop an enterprise is related to actualising one's personal life situation. Self-actualisation relates not only to realising one's skills and expertise, but to any personal life consideration where individuals assign high value (Schacter et al., 2011; Corbett, 2007). For the study's respondents, gendered life events played an important role in framing the perceptions of role demands in a way that links work and life contexts:

"With the birth of my son, these new emotions, knowledge and insights have shaped my business strategy. Perhaps that is why for me there was no doubt - if the company were to be a retail brand, it would be a brand of children's clothes. I have something to tell the world through it." (Participant H) 
The interviews provided evidence that women entrepreneurial leaders perceived their role demands in broad, rather than narrow, terms, and they emphasised the importance of both financial and non-financial returns. They also mold financial and non-financial outcomes as exemplified by one interviewee to whom the link between employee well-being and performance was clear:

"I have created such an organisation in which every employee is able to work productively and is aware that she/he is being taken care of. I am very conscious about employees' well-being in work. It's very important that when an employee comes to work - she/he is free from any other concerns. What we have achieved is that we are a successful organisation that can attract the best people, so that I am confident we can handle competition very well." (Participant L)

As exemplified above, the study participants understood their role demands in the context of positive leadership that can be defined as 'the systematic and integrated manifestation of leadership traits, processes, intentional behaviors' enhancing 'developmental potential of leaders, their followers and their organisations over time and across contexts' (Youssef-Morgan \& Luthans, 2013: 42). In addition, in observable instances positive leadership 'adds value, leaving the context, process or outcomes within which it takes place elevated, uplifted, improved, or somehow better' Youssef-Morgan \& Luthans, 2013). As research asserts, enacting positive leadership is tightly knitted to caring for all stakeholders and for the wider environment (Maak \& Pless, 2006). Hope, efficacy, resilience, and optimism are some of characteristics exhibited by positive leadership. (Youssef-Morgan, and Luthans, 2013). From this perspective, accountability to followers, partners and other parties involved was key for our respondents in linking role demands with selfactualisation. For example, Participant E stated that the critical success factors are "ability to withstand difficulties and not to give up easily; courage to move on; honesty and openness; and seeing good in people." Participant D, however, stated that in business:

"...one needs courage and ability to overcome challenges and obstacles; it is essential to walk over sharp angles - and learn how to negotiate. In my experience I sometimes had a momentary desire to not deal with challenges in the evening, but the next morning I am seeking ways to solve the problems. The main reason is my accountability to those people who believe in me." (Participant D) 
Our interviewees also experienced tensions and pressure related to demands of resilience. Resilience as the unceasing ability to bounce back, to cope, renew and revitalize, was perceived by women entrepreneurs in our study as a key role demand in sustaining effective leadership. For instance, one participant talked about courage when maintaining discomforting communications and emphasised that she has to achieve win-win outcomes for all involved:

"Well, if I see that some actions that my partners are undertaking do not make sense to me, or if I believe that they will not bring positive results - I always speak about that, irrespective to whatever discomfort it causes to me or them. For me, it's always important to have win-win outcomes among all of us." (Participant N)

The findings regarding role demands highlight two important items for further analysis. First, the results elucidate significance of affective competencies to the success of entrepreneurship (see Baum and Locke, 2004; Baron, 2008). Second, the results indicate the meaningfulness of interpersonal relational orientations that women experience in leading enterprises in Kazakhstan. Literature often refers to female leaders' relational capabilities as a highly demanded leadership advantage in contemporary, dynamic environments (James, 2012). Such capabilities include emotional maturity; honouring feelings in oneself and others; displaying a trusting disposition; cultivating productive working relationships; demonstrating highly developed interpersonal communication style; and being hopeful and inspiring for others. The value of such relational qualities is increasingly important for today's complex business environments because competence-based leadership can focus on delivery of the present value based on past performance, while relational qualities can bring about new ways which might be more relevant to future outcomes (Kakabadse \& Kakabadse, 1999). Overall, the role demands that women experience in entrepreneurial leadership roles were webbed around the capacity to make sense of interpersonal, organisational and societal context. They then acted on the context demands by meaningfully drawing their leadership strategies on their personal experiences and their values of accountability to people and communities. 


\section{Role Constraints}

The second dimension in the DCC model is role constraints. Role constraints were perceived as both complex and pervasive by interviewees and often difficult to pin down: "At that time it was easier to say in what I was not constrained, because I felt that I was constrained virtually in everything” (Participant D). Moreover, in alignment with Stewart (1982), as well as Katz and Sheperd (2003), data suggested that women emphasise the importance of mental models that entrepreneurs develop in regard to constraints to entrepreneurial effectiveness:

"I simply can't stand hearing from my employees that something is impossible.

The last time when I heard it I suggested a couple of dozen ways to look at the problem. I think it's a matter of how you think about it." (Participant B)

Women entrepreneurial leaders also perceived themselves as seriously constrained if all parties in the enterprise did not achieve shared understanding. In order to overcome these constraints, participants underlined the importance of well-functioning teams, emphasising the relevance of team dynamics and composition:

"I spent two years to gather a team that I can rely upon. The team in which everyone understands one's own role and what we are doing altogether. Every person was precious. I didn't want to lose anyone because then we would not be able to proceed." (Participant L)

In relation to role constraints, interview data demonstrate the significance of flexible behaviour in the context of dynamic nature of entrepreneurship. For instance, participants perceived certain limitations to their leadership behaviours once the established structures became too rigid:

"Well, once the business is well-established, it can develop only within certain frames. Those that are clear for customers. They are well structured for accomplishing projects, but over time you start to understand that founding success principles restrict you from developing. ... Now I like how market reacts to our renewed status - almost every day we receive promising offers." (Participant $M)$ 
Our findings support Stewart's (1982) suggestion that the area of constraints is flexible and dynamic - whereby constraints make certain choices unavailable, but foster others. The data suggest that when in need to search for alternative choices, women entrepreneurs in our study consider acceptance of reasonable risks, but simultaneously tend to connect new choices to the existing business competencies:

"At that time the business was paralysed. We had no orders; debts seemed to be endless. I suggested the idea, which at that time seemed like nonsense. We had to move from providing the service for someone else's product to providing our own services, for example by offering our own training courses. It seemed unrealistic, but I could convince [myself and the team] that we had all the necessary competencies on which we can build our new direction." (Participant D)

Contradictory results have been received in relation to the need to accommodate family and business commitments (Kirkwood \& Tootell, 2008; McKie, Biese \& Jyrkinen, 2013; Sevä \& Öun, 2015). Yet, overall, our participants did not necessarily perceive a need to strictly draw a dividing line between family and business:

"To me, business is not a means to extract high profits. This is an opportunity first, to provide for the best conditions to educate my children; and second, to enhance the quality of my family life." (Participant J)

As the previous section elucidated, women often perceive business as a contributor to the wholeness of their life situation and as part of their self-actualisation. Accordingly, they develop enterprises in ways that business and family can reinforce and complement each other. As interviewees repeatedly emphasised, the principal constraints that were experienced by women entrepreneurial leaders in Kazakhstan were the lack of shared meanings, lack of resources and rigid contextual structures.

\section{Role choices}


The analysis of the interview data reveals that role choices are experienced by the study participants as their individual way of enacting the best option available to them, which may or may not be obvious to others. In choosing the best option, participants considered role demands and role constraints simultaneously together with their perceived creativity and ability to innovate and find a way forward. Pursuing the chosen best option, the study participants exercise their entrepreneurial leadership capability by identifying, choosing and enacting the "pertinent pathways forward when direction is obscure(d)' and when the pathway through may not be easy (Kakabadse and Kakabadse, 1999: 321). The results of the study demonstrate that female leaders in entrepreneurial setting exercised choice but within the boundaries set by demand and constraint parameters. The exercise of choice is often framed as embracing certain options:

\begin{abstract}
"I believe it's a matter of choice. Sometimes what we do may seem illogical for a retail brand, but we don't think of it as simply a buy-and-sell business. So, we sometimes do something different." (Participant P)
\end{abstract}

Furthermore, women entrepreneurs adopt either 'soft' or 'hard' behaviours depending on the specific contextual and situational circumstance:

"I can't say that I am a harsh manager; however, I am firm and consistent. The job is like that, which is impossible without such qualities. However, at the same time in my job it is impossible to be effective without such qualities as compassion, sympathy and leniency." (Participant L)

This finding suggests that women in leadership roles exercise choice within a given scope of task complexity, personality, organisational determinants, rather than merely comply with boundaries of gender roles (Eagly \& Johnson, 1990). Therefore, it is particularly important to conceptualise individuals' leadership effects through the lens of the context.

In reference to specific choices that women entrepreneurs experience in leadership roles, the findings suggest two persistent themes: teamwork and learning. In line with extant literature (e.g. Eagly and Johannesen-Schmidt, 2001; Lipman-Blumen, 1992; Moore et al., 2011), our 
respondents expressed the tendency to choose collaborative behaviour as an important leadership strategy. The collaborative behaviour is also a common feature of the female understanding of leadership, where leadership is viewed as a means to social transformation and where women's collaborative styles of leadership are viewed as integral to achieving an equitable society (Batliwala, 2010). The interviewees also emphasised trust, respect and teamwork:

"I am infinitely proud of my team, with which we have developed very close relationships. It is important to establish trust and respect, for which I worked very hard." (Participant L)

In addition to the perception of teamwork as an important condition to create a positive organisational climate (Eagly \& Carli, 2007; Eagly et al., 2003), interviewees perceived teamwork as an essential tool to maximise the team members' competencies through knowledge exchange and mutual learning. Teamwork and collaboration reflect the understanding that leaders are more effective as a team and that individuals are more motivated and energetic when emotionally connected with others who are important to them (Grant, 2007). Teamwork emerged as a theme interrelated with another persistent leadership role choice, i.e., the need to engage in individual and collective learning for the development of enterprise. Participants perceived succession and transfer of expertise as an important condition for effective goal achievement:

"This is a mutual process - I also learn from my team. In all my projects, I gradually came up with the team that I believed best suited to the objectives. But it was never the case that I came and replaced the whole team. It's important that each project has succession of experience, common history, values. " (Participant D)

Moreover, in addition to giving clear performance standards, the interviewees believed that career development practices and training opportunities can serve as important non-monetary motivators:

"Good work shall be encouraged, talent shall be supported. From my experience I can say that non-monetary motivation is very effective." (Participant J) 
Lastly, in many respects, women entrepreneurial leaders choose to act as role models of effective behaviour, which is seen as a way to further leverage their followers' commitment:

"I think leadership is making an example. Role-modelling. I learned leadership from my dad that "the chief should serve as an example". Every Saturday I myself work as a sales person in a shop. Colleagues and partners believe in your principles and approaches only when they see you do it." (Participant H)

The participants also emphasised promotion of individual and collective learning as a key leadership capability. Our findings show that women entrepreneurial leaders perceive knowledge transfer as a developmental activity:

"I expect my team members to listen to each other, exchange knowledge, generate ideas. Competent staff increase trust in our services among partners and customers. "(Participant M).

Whilst there is a relatively small research stream that views the entrepreneur as a learner and the entrepreneurship as organised learning (Franco \& Haase, 2009; Karatas-Ozkan \& Chell, 2010; Karatas-Ozkan, 2011), our findings contribute to this research by conceptualising entrepreneurship as a co-developmental activity. Notably, women entrepreneurs perceive both team-working and shared learning as essential determinants of maintaining a sufficient degree of flexibility within organisations, which is critical to the success of the enterprise:

"I always make myself available by e-mail. I think this is very motivating for managers and enables[them] to solve issues quickly. I think this helps to build a flexible organisation that can quickly react to the environmental changes." (Participant D)

In summary, we conceptualise choices of female leaders in entrepreneurial firms as co-developing collaborative behaviour that emphasises positive relation-building, role-modelling and mutual 
learning. This is aligned with Karatas-Ozkan and Chell's (2015) suggestion that gender may inhabit a lived social-relation space that bridges identity and different forms of power relations. Hence, the present study further emphasises that relational qualities support leadership behaviours in entrepreneurial firms.

\section{Discussion and Conclusion}

The paper's findings contribute to the conceptual understanding of female leaders' experience of leadership demands, constraints and choices within entrepreneurial settings in Kazakhstan's transition economy. Table 2 provides a summary of our key findings along the dimensions of role demands, role constraints and role choices, and role beliefs. The empirical evidence demonstrates the importance of the context for the understanding of female entrepreneurial leadership. Furthermore, our research highlights that role beliefs is an important dimension that needs to be considered in addition to role demands, role constraints and role choices if we are to better understand the interplay between gender, entrepreneurship and leadership. Our findings show that female leaders in entrepreneurial firms in the Kazakhstani context believe that a key contribution of leaders is the creation of value, well-being and benefit for a wide range of stakeholders including employees, communities and the organisation itself. Women's effective interaction with the influences from the uncertain and changing environment also ensures the firm's success. Furthermore, women entrepreneurial leaders perceive the creation of results that are beneficial to all stakeholders and the wider community as an important dimension and demand of their leadership role. They emphasise the importance of both financial and non-financial returns, as well as sustainable outcomes of their entrepreneurial activities. We can conclude that women perceive the effectiveness of leadership as contribution to both profitability and well-being of their collaborative network, which encompasses leaders and other participants' personal backgrounds, entrepreneurial objectives, wider context as well as environment (Corbett, 2007; Elliot \& Stead, 2008). Hence, the findings stimulate further research whilst they complement the DCC model.

\section{INSERT TABLE 2 ABOUT HERE}

Notably, women aim to establish collaborative networks with internal and external stakeholders 
and these networks are relational and interpersonal (Rosener, 1990; Elliot \& Stead, 2008). The findings demonstrate that female leaders in the context of Kazakhstan are particularly sensitive to the well-being of community in which they operate as they consider their enterprise an integral part of the community. This finding is consistent with the growing research evidence suggesting socially-oriented intentions and outcomes of the women-led enterprises (Soares et al., 2011). Moreover, findings suggest that further research is necessary in order to conceptualise how women can lead an enterprise that would provide positive social effects without compromising the sole existence of an organisation in the long run. This finding makes a significant contribution to the evidence base that supports literature on entrepreneurial leadership in a sense that, by developing an enterprise via innovative approaches, female leaders may positively contribute to society's development along multiple dimensions, such as income generation, balancing family life and professional growth, educational and training needs, community development and stakeholder engagement, rather than going for a high-risk investment and expansion as a basis for profit-driven organisational strategy.

The findings show that women entrepreneurial leaders who are highly educated experienced tensions at the intersection of role demands, namely around effectively managing role constraints related to resource scarcity. One possible implication of this finding is that we can explore women entrepreneurial leadership in relation to resource-based capabilities (Chandler \& Hanks, 1994). However, the extant literature does not provide sufficient insights into the explanation of the effects of such perceptions of quality in relation to behaviour and performance of entrepreneurial firms. Hence, further research may address this topic.

The study proposes a new conceptual framing of female entrepreneurial leadership, which we conceptualise as a co-developing activity that aims to produce positive outcomes for all participants, as well as for the environment within which entrepreneurs operate. This female entrepreneurial leadership is holistic as it emphasises integration of work and life priorities, focuses on personal development and embraces a wider appreciation of multiple dimensions of running a business. Additionally, the theoretical contribution of this study lies in a novel conceptualisation of leadership perceptions and experiences as dynamically determined by interaction of individual and contextual factors shaped by women entrepreneurs' gender. This contribution responds to the 
identified need for deeper understanding of the links between women-leaders and entrepreneurship, as well as the dynamic interactions between the context and process of entrepreneurship (de Bruin et al., 2006; Hughes et al., 2012). The results also support positive leadership theory and its components, resilience, innovation and optimism (Youssef-Morgan \& Luthans, 2013) as our participants exhibited these behaviours. Majority of research on entrepreneurial women in leadership role are focused on leadership success, such as style and effectiveness differences between men and women as well as the invisible barriers keeping women out of elite leadership positions. The study's results show that women in the leadership roles in Kazakhstan's entrepreneurial organisations are concerned with success, but not in an instrumental way; rather, they focus on co-creative and developmental aspects of it. The findings also have practical implications as the study provides insights into how women entrepreneurs can provide better leadership in the entrepreneurial context of Kazakhstan. Our study complements findings by Luthans and Ibrayeva (2006) who explored the development of entrepreneurship in transition economies including Kazakhstan and called for further research to conceptualise the role of leaders in facilitating a successful enterprise with positive effects to the wider community, especially within the context of a transition economy. The lack of a market-oriented culture during transition from a planned to a market economy may pose a negative influence on entrepreneurship (Luthans \& Ibrayeva, 2006). Using the DCC model, our findings show that building enterprise via implementing a holistic and balanced leadership that is also oriented on development can further entrepreneurial capacity and substantially enhance entrepreneurial behaviours in such contexts. Role modelling of effective leaders may also significantly contribute to enhancement of positive perceptions of entrepreneurship in the country and create more favourable conditions for business. Whilst this paper focuses on Kazakhstan, further studies may apply the DCC model to investigation of leadership roles that women entrepreneurs play in other contexts. The findings of our study confirm Jennings and Brush's (2013; 679) insights about entrepreneurship being ' not a gender-neutral phenomenon', but rather an outcome of process of social construction that takes place in gender-unequal social contexts. Following Jennings and Brush (2013), who identify the roots of research on women entrepreneurship in gender and occupations literature as well as feminist theory, further ways to conceptualise female entrepreneurship include:

a) Adopting a gender-based or feminist perspective overall as a framework for the field of 
entrepreneurship, (Gundry and Welsch, 2001; Ahl and Marlow, 2012)

b) Diversifying the body of evidence on women entrepreneurs, by including differentiating factors in terms of their entrepreneurial outcomes (eg: size of enterprise, industry, strategic intent, performance) (Gundry and Welsch, 2001)

c) Taking an in-depth approach in terms of the differences between men and women as entrepreneurs (Brush, 2009)

The study's limitations pertain to the contextual specificity of attributes that interviewees possess as well as generalising inductively from qualitative data generated in the field (Bendassolli, 2013); nonetheless, this is also one of the ways to respond to existing research gaps which have been highlighted when studying entrepreneurship in context, following in particular, Tlaiss (2003) as well as Al Dajani and Marlow (2010) who have identified the challenge of reporting research findings from a non-Western, non-Anglo-Saxon setting. Ours, as well as similar research, also responds to Mirchandani (1999), who invites inductive, qualitative-based inquiry that can further support our understanding of entrepreneurship as a 'gendered' activity, since relevant research evidence outside a standard 'male normative' framework is still limited (Fielden and Davidson, 2005). This invitation is the seed of a future research agenda which can focus on further evidence from developing countries/transition economies in order to further confirm and clarify the nuances involved in terms of the outcomes of our study. Furthermore, a comprehensive model with testable propositions could be developed that highlights the links between entrepreneurial activity, specific characteristics of the entrepreneurial organisations involved and the macro-meso-micro dimensions of the social construction which defines entrepreneurial development.

Additionally, access-specific issues might provide a limitation in themselves, as the snowballing sampling is highly dependent on interviewees' networks. Nonetheless, identification of differences in values and attitudes is an important part of research that aims to conceptualise female leadership. From this perspective, the study's insights contribute towards the body of knowledge on female leaders in entrepreneurial businesses and open up new areas for future research from women's perspective; these pertain, in particular, to leadership perceptions and experiences as dynamically determined by a rich interaction of individual and contextual factors shaped by women entrepreneurs' gender. 


\section{References}

Ahl, H (2006) Why research on women entrepreneurs needs new directions. Entrepreneurship: Theory \& Practice, 30(5): 595-621 http://dx.doi.org/10.1111/j.1540-6520.2006.00138.x

Ahl, H., Marlow, S. (2012) Exploring the dynamics of gender, feminism and entrepreneurship: advancing debate to escape a dead end?. Organization, 19(5): 543-5 http://dx.doi.org/10.1177/1350508412448695

Aidis, R., Welter, F., Smallbone, D., \& Isakova, N. (2007). Female entrepreneurship in transition economies: the case of Lithuania and Ukraine. Feminist Economics, 13(2), 157-183.

Ajzen, I., \& Fishbein, M. (2000). Attitudes and the attitude-behaviour relation: Reasoned and automatic processes. European Review of Social Psychology, 11, 1-33.

Al Dajani, H and Marlow, S (2010) Impact of women's home-baed enterprise on family dynamics: evidence from Jordan, International Small Business Journal, 28 (5), 470-486

Babalola, S. S. (2009). Women entrepreneurial innovative behaviour: the role of psychological capital. International Journal of Business and Management, 4(11), 184-192.

Baron, R. A. (1998). Cognitive mechanisms in entrepreneurship: why and when entrepreneurs think differently than other people. Journal of Business Venturing, 13, 275-294.

Baron, R. A. (2008). The role of affect in the entrepreneurial process. Academy of Management Review, 33(2), 328-340.

Bass, B. M. (1990). Leadership and Performance Beyond Expectations (2nd ed.). New York: Free Press.

Bass, B. M. (1999). Two Decades of Research and Development in Transformational Leadership, European Journal of Work and Organisational Psychology, 8 (1), 9-32.

Baum, J. R., \& Locke, E. A. (2004). The relationship of entrepreneurial traits, skill and motivation to subsequent venture growth. Journal of Applied Psychology, 89(4), 587-598.

Baum, J. R., Locke, E. A., \& Kirkpatrick, S. A. (1998). A longitudinal study of the relation of vision and vision communication to venture growth in entrepreneurial firms. Journal of 
Applied Psychology, 83, 43-54.

Batliwala, S. (2010). 'Feminist Leadership for Social Transformation: Clearing the Conceptual Cloud'. Bangalore: CREA, July, https://www.justassociates.org/sites/justassociates.org/files/feminist-leadership-clearingconceptual-cloud-srilatha-batliwala.pdf (accessed 10 November 2015).

Baxter, J., \& Al-A'ali, H. (2014). Your situation is critical...: the discursive enactment of leadership by business women in Middle Eastern and Western European contexts. Gender and Language, 8(1), 91-116 25

Bendassolli, P. F. (2013). Theory building in qualitative research: reconsidering the problem of induction. Forum Qualitative Sozialforschung/Forum: Qualitative Social Research, 14(1), $1-50$.

Bennett, R. \& Dann, S. (2000) The changing experience of Australian female entrepreneurs. Gender, Work and Organization, 7, 2, 75-83.

Bernard, R. B., \& Ryan, G. W. (2010). Analyzing Qualitative Data. Thousand Oaks, CA: Sage.

Bhuiyan, S. H., \& Amagoh, F. (2011). Public sector reform in Kazakhstan: issues and perspectives. International Journal of Public Sector Management, 24(3), 227-249.

Bjerke, B., \& Rämö, H. (2011). Entrepreneurial Imagination: Time, Timing, Space and Place in Business Action. Cheltenham: Edward Elgar Publishing Limited.

Boal, K. B., \& Hooijberg, R. (2000). Strategic leadership research: moving on. Leadership Quarterly, 11(4), 515-549.

Bourne, K.A. \& Calás, M.B. (2013). Becoming 'Real' Entrepreneurs: Women and the Gendered Normalization of 'Work'. Gender, Work and Organization, 20, 4, 425-438.

Browne, K. (2005). Snowball sampling: using social networks to research non-heterosexual women. International Journal of Social Research Methodology, 8(1), 847-860.

Bruni, A., Gherardi, S. \& Poggio, B. (2004) Doing gender, doing entrepreneurship: an ethnographic account of intertwined practices. Gender, Work \& Organization, 11 (4): 406429. 
Brush, C (2009) Women entrepreneurs: a research overview in Basu, A., Casson, M., Wadeson, N and Yeung, B, (eds.) The Oxford Handbook of Entrepreneurship, OUP, DOI: 10.1093/oxfordhb/9780199546992.003.0023

Bandura, A. (1986). Social Foundation of Thought and Action: A Social Cognitive View, PrenticeHall, Englewood Cliffs, NJ.

Campbell, J. (2002). Reference and Consciousness. Oxford University Press.

Chandler, G. N., \& Hanks, S. H. (1994). Market attractiveness, resource-based capabilities, venture strategy, and venture performance. Journal of Business Venturing, 9(4), 331-349.

Choi, Y. R., and D. A. Shepherd (2004). "Entrepreneurs' Decisions to Exploit Opportunities," Journal of Management 30(3): 377-395.

Clark, J.A. (2006). Field Research Methods in the Middle East. Symposium, 417-424, available online at www.apsanet.org (accessed 20 October 2014).

Cogliser, C. C., \& Brigham, K. H. (2004). The intersection of leadership and entrepreneurship: mutual lessons to be learned. Leadership Quarterly, 15, 771-799.

Corbett, A. (2007). Learning asymmetries and the discovery of entrepreneurial opportunities. Journal of Business Venturing, 22, 97-118.

Daily, C., \& Dalton, D. (1993). Board of directors leadership and structure: control and performance implications. Entrepreneurship Theory and Practice, 17, 65-81.

Datta, P \& Gailey, R (2012) Empowering women through social entrepreneurship: case study of a women cooperative in India, Entrepreneurship Theory and Practice, May, 569. DOI: 10.1111/j.1540-6520.2012.00505.x

Davis, A., \& Shaver, K. (2012). Understanding gendered variations in business growth intentions across the life course. Entrepreneurship Theory and Practice, May, 495-512.

de Bruin, A. Brush, C. \& Welter, F. (2006) Introduction to the Special Issue: Towards building cumulative knowledge on women's entrepreneurship, Entrepreneurship Theory and Practice, 30(5): 585-593.

Den Hartog, D. (2003). What indeed do managers do? Some reflections on Rosemary Stewart's work. Leadership Quarterly, 14, 221-229. 
Drucker, P. F. (1985). Innovation and Entrepreneurship. London: Pan Books Ltd.

Dzisi, S (2008) "Entrepreneurial activities of indigenous African women: a case of Ghana", Journal of Enterprising Communities: People and Places in the Global Economy, Vol. 2 Iss: 3, pp.254 - 264

Eagly, A. H., \& Carli, L. L. (2007). The female leadership advantage: an evaluation of the evidence. The Leadership Quarterly, 14, 807-834.

Eagly, A. H., \& Johannesen-Schmidt, M. C. (2001). The leadership styles of women and men. Journal of Social Issues, 57(4), 781-797.

Eagly, A. H., \& Johnson, B. T. (1990). Gender and leadership style: a meta-analysis. Psychological Bulletin, 108, 233-256.

Eddleston, K., \& Powell, G. (2012). Nurturing entrepreneurs' work-family balance: a gendered perspective. Entrepreneurship Theory and Practice, May, 513-541.

Ehrlich, S. B., De Noble, A. F., Moore, T., \& Weaver, R. R. (1994). After the cash arrives: a comparative study of venture capital and private investor involvement in entrepreneurial firms. Journal of Business Venturing, 9, 67-82.

Elliott, C., \& Stead, V. (2008). Learning from leading women's experience: towards a sociological understanding. Leadership, 4(2), 159-180.

Ensley, M. D., \& Pearce, C. L. (2001). Shared cognition in top management teams: implications for new venture performance. Journal of Organizational Behavior, 22, 145-160.

Erikson, E. (1959). Identity and the Life Cycle. Bloomington: Indiana University Press.

Fairhurst, G. T. (2009). Considering context in discursive leadership research. Human Relations, 62(11), 1607-1633.

Fielden S \& Davidson M (eds) (2005) International Handbook of Women and Small Business Entrepreneurship. London: Edward Elgar.

Fondas, N., \& Stewart, R. (1994). Enactment in managerial jobs: a role analysis. Journal of Management Studies, 31(1), 83-103. 
Foss, L (2010) Research on entrepreneur networks: The case for a constructionist feminist theory perspective, International Journal of Gender and Entrepreneurship, 2(1), 83 - 102

Franco, M., \& Haase, H. (2009). Entrepreneurship: an organisational learning approach. Journal of Small Business and Enterprise Development, 16(4), 628-641.

Gaglio, C. M. (2004). The Role of Mental Simulations and Counterfactual Thinking in the Opportunity Identification Process. Entrepreneurship Theory and Practice, 28(6): 533-552.

Garcia, M. C., \& Welter, F. (2011). Gender identities and practices: interpreting women entrepreneurs' narratives. International Small Business Journal, 31(4), 384-404.

Gilligan, C. (1982). In a Different Voice: Psychological Theory and Women's Development. Cambridge, MA: Harvard University Press.

Grant, A. M. (2007). Relational job design and the motivation to make a prosocial difference. Academy of Management Review, 32(2), 393-417.

Guest, G., MacQueen, K. M., \& Namey, E. (2012). Applied Thematic Analysis. Thousand Oaks, CA: Sage.

Gundry, L \& Welsch, H (2001) The ambitious entrepreneur: high growth strategies of womenowned enterprises, Journal of Business Venturing, 16, 5, 453-470

Hargittai, E. and Shafer, S, (2006). Differences in Actual and Perceived Online Skills: The Role of Gender', Social Science Quarterly, 87(2), 432-448.

Heckathorn, D. D. (1997). Respondent-driven sampling: a new approach to the study of hidden populations. Social Problems, 44(2), 174-199.

Helgesen, S. (1995). The Female Advantage: Women's Ways of Leadership. New York: Doubleday.

House, M., \& Solberg, A. (2004). Gender-related boardroom dynamics: how women make and can make contributions in corporate boards. EURAM Conference, Scotland.

House, R. J., Hanges, P. J., Javidan, M., Dorfman, P. W. \& Gupta, V. (2004). Culture, Leadership, and Organizations. The GLOBE Study of 62 Societies. London: Sage.

Hubner, W. (2009). SME development in countries of central Asia (Kazakhstan, Kyrgyzstan and Uzbekistan: constraints, cultural aspects and role of international assistance. Vienna: UNIDO. https://www.unido.org/fileadmin/import/userfiles/puffk/huebner.pdf (accessed 
November 2013).

Hughes, K., Jennings, J., Brush, C., Carter, S., \& Welter, F. (2012). Extending women's entrepreneurship research in new directions. Entrepreneurship Theory and Practice, May, 429-442.

Hutchinson, S.A. (1988), “Grounded theory”, in R.R. Sherman and R.B. Webb (eds), Qualitative Research in Education: Focus and Methods. Falmer, London, 123-140.

Ibrayeva, E. S. (1999). Entrepreneurship in transitionary economies: testing a social cognitive model (paper AAI9929206). ETD Collection for University of Nebraska - Lincoln.

Izyumov, A. \& Razumnova, I. (2000). Women Entrepreneurs in Russia: Learning to survive the market, Journal of Developmental Entrepreneurship; 5,1, 1-19.

Idris, A. (2009). Management styles and innovation in women-owned enterprises. African Journal of Business Management, 3(9), 416-425.

Ireland, R.D., Hitt, M.A., Camp, S. M. and Sexton, D. L. (2001). Integrating entrepreneurship with strategic management actions to create firm wealth. The Academy of Management Executive, 15(1), 49-63.

Jamali, D (2009) Constraints and opportunities facing women entrepreneurs in developing countries: a relational perspective, Gender in Management: An International Journal, 24(4), 232-251

James, A. (2012). Conceptualising "woman" as an entrepreneurial advantage: a reflexive approach. In K. Hughes, \& J. E. Jennings (Eds). Global Women's Entrepreneurship Research: Diverse Settings, Questions and Approaches. Cheltenham: Edward Elgar Publishing Limited.

Jensen, S. M., \& Luthans, F. (2006). Entrepreneurs as authentic leaders: impact on employees' attitudes. Leadership \& Organization Development Journal, 27(8), 646-666.

Jennings, J \& Brush, C (2013) Research on Women entrepreneurs: challenges to (and from) the broader entrepreneurship literature? The Academy of Management Annals, 7, 1

Kakabadse, A. P., \& Kakabadse, N. (1999). Essence of Leadership. London: Thomson International. 
Kakabadse, N., \& Kakabadse, A. (2005). Discretionary leadership: from control/co-ordination to value co-creation through polylogue. In G. L. Cooper (Ed.). Leadership and Management in the 21st Century. Business Challenges of the Future (pp. 57-106). Oxford: Oxford University Press.

Kakabadse, N., Lee-Davies, L., \& Kakabadse, A. (2009). Leadership discretion: a developmental experience. Strategic Change, 18, 111-124.

Kant, I. (1932). Critique of Pure Reason, trans. N. Kemp Smith. London: Macmillan.

Karataş-Özkan, M., \& Chell, E. (2012). Nascent Entrepreneurship and Learning. Cheltenham: Edward Elgar Publishing Limited.

Karatas-Ozkan, M. (2011). Understanding relational qualities of entrepreneurial learning: towards a multi-layered approach. Entrepreneurship \& Regional Development, 23(9-10), 877-906.

Karataş-Özkan, M., \& Chell, E. (2015). Gender inequalities in academic innovation and enterprise: a Bourdieuian analysis. British Journal of Management, 26(1), 109-125.

Katz, J.A., \& Sheperd, D. A. (2003). Cognitive approaches to entrepreneurship research, advances in entrepreneurship. Firm Emergence and Growth, 6, 1-10.

Kennedy, Tracy, Barry Wellman, and Kristine Klement. (2003), 'Gendering the Digital Divide', IT \& Society, 1(3), 149-172.

Kirkwood, J., \& Tootell, B. (2008). Is entrepreneurship the answer to achieving work-family balance? Journal of Management and Organization, 14(3), 285-302.

Kobia, M., \& Sikalieh, D. (2010). The meaning of entrepreneurship. Journal of European Industrial Training, 34(2), 110-127.

Kolb, J. (1999). The effect of gender role, attitude toward leadership, and self-confidence on leader emergence: implications for leadership development. Human Resource Development Quarterly, 10(4), 305-320.

Kotter, J.P. (1988). The Leadership Factor. New York, NY: The Free Press.

Kreiser, P.M., Marino, L.D., Dickson, P., \& Weaver, K.M. (2010). Cultural influences on entrepreneurial orientation: the impact of national culture on risk-taking and proactiveness in SMEs. Entrepreneurship Theory and Practice, 34(5), 959-983. 
Kroeck, G. (2003). Rosemary Stewart on management: behavioral scribe, squire of theory, pragmatic scientist. The Leadership Quarterly, 14(2), 204-214.

Kuratko, D., \& Hodgetts, R. (2009). Entrepreneurship, Theory, Process, Practice (8th ed.). Mason, $\mathrm{OH}$ : South Western Cengage Learning.

Lee-Gosselin, H., \& Grise, J. (1990). Are women owner-managers challenging our definitions of entrepreneurship? An in-depth survey. Journal of Business Ethics, 9, 423-435.

Leitch, C., MaMullan, M., \& Harrison, T. (2009). Leadership development in SMEs: an action learning approach. Action Learning: Research and Practice, 6, 243-264.

Lewis, P. (2006). The quest for invisibility: female entrepreneurs and the masculine norm of entrepreneurship. Gender, Work \& Organization, 13(5), 453-469.

Lord, R. G., \& Hall, R. J. (2005). Identity, deep structure and the development of leadership skill. Leadership Quarterly, 16, 591-615.

Lowe, K. B. (2003). Demands, constraints, choices and discretion: an introduction to the work of Rosemary Stewart. The Leadership Quarterly, 14(2), 193-197.

Luthans, F., \& Ibrayeva, E. S. (2006). Entrepreneurial self-efficacy in central Asian transition +economies: quantitative and qualitative analyses. Journal of International Business Studies, $37,92-110$.

Lyne de Ver, H. (2008). 'Leadership, Politics and Development: A Literature Survey', LECRP Background Paper. Available at http://www.dlprog.org (accessed 20 October 2015).

Maak, T., \& Pless, N. (2006). Responsible leadership in a stakeholder society: a relational perspective. Journal of Business Ethics, 66(1), 99-115.

Mair, J., \& I. M. Lanuza. (2005). Social entrepreneurship research: A source of explanation, prediction and delight. IESE Business School Working Paper No. 546. http://ssrn.com/ abstract-673446.

Manz, C. C., Bastien, D. T., Hostager, T. J., \& Shapiro, G. L. (1989). Leadership and innovation: a longitudinal process view. In A. H. van de Ven, H. L. Angle, \& M. S. Poole (Eds). Research on the Management of Innovation: The Minnesota Studies. New York, NY: Oxford University Press. 
Matzler, K., Schwarz, E., Deutinger, N., \& Harms, R. (2008). Relationship between transformational leadership, product innovation and performance in SMEs. Journal of Small Business and Entrepreneurship, 21(2), 139-152.

McKie, L., Biese, I., \& Jyrkinen, M. (2013). 'The Best Time is Now!' : The Temporal and Spatial Dynamics of Women Opting in to Self - Employment. Gender, Work \& Organization, 20(2), 184-196.

Miles, M., \& Huberman, A. M. (1994). Qualitative Data Analysis (2nd ed.). Thousand Oaks, CA: Sage Publications, Inc.

Mirchandani, K. (1999) Feminist insight on gendered work: new directions in research on women and entrepreneurship. Gender, Work \& Organization, 6,4, 224-35.

Moore, D. P., Moore, J. L., \& Moore, J. W. (2011). How women entrepreneurs lead and why they manage that way. Gender in Management: An International Journal, 26(3), 220-233.

Mumford, M. D. (1986). Leadership in the organizational context; conceptual approach and its application. Journal of Applied Social Psychology, 16, 212-226.

Mumford, M. D., Friedrich, T. L., Caughron, J. J., \& Byrne, C. L. (2007). Leader cognition in realworld settings: how do leaders think about crises? Leadership Quarterly, 18, 515-543.

Nicolopoulou, K, Kakabadse, N, Nikolopoulos, KP, Alcaraz, J, Sakellariou, K (2016, forthcoming)' Cosmopolitanism and Transnational Elite entrepreneurial practices: manifesting the cosmopolitan disposition in an cosmopolitan city' Society and business review, vol 11, 3

Osborn, R., Hunt, G., \& Jauch, L. (2002). Toward a contextual theory of leadership. Leadership Quarterly, 13, 797-837.

Özbilgin, M.F., Beauregard, T.A., Tatli, A., \& Bell, M.P. (2011), Work-life, diversity and intersectionality: a critical review and research agenda, International Journal of Management, 13(2), 177-198.

Patton, M. Q. (1987). How to Use Qualitative Methods in Evaluation. Thousand Oaks, CA: Sage Publications, Inc.

Pech, R. J., \& Cameron, A. (2006). An entrepreneurial decision process model describing 
opportunity recognition. European Journal of Innovation Management, 9(1), 61-78.

Phillips, M., \& Knowles, D. (2012). Performance and performativity: undoing fictions of women business owners. Gender, Work \& Organization, 19(4), 416-437.

Pless, N. M. (2011). Women leading a responsible global business. In P. Werhane, \& M. PainterMorland (Eds). Leadership, Gender, and Organization, Issues in Business Ethics, 27 (pp. 245-258). New York: Springer.

Renko, M., Tarabishy, Ayman El, Carsrud, A. L. and Brännbac, M. (2015), Understanding and Measuring Entrepreneurial Leadership Style, Journal of Small Business Management, 53(1): $54-74$.

Rosener, J. (1990). Ways women lead. Harvard Business Review, November-December, 119-125.

Saldana, J. (2009). The Coding Manual for Qualitative Researchers. Thousand Oaks, CA: Sage.

Schacter, D. L., Gilbert, D. T., \& Wegner, D. M. (2011). Human Needs and Self-Actualization. Psychology (2nd ed.). New York: Worth, Incorporated.

Schein, E. H. (1983). The role of the founder in creating organizational culture. Organizational Dynamics, Summer, 13-28.

Schumpeter, J. (1934). The theory of economic development: an inquiry into profits, capital, interest, and the business cycle. Cambridge: Harvard University Press.

Scott, L., Dolan, C., Johnstone- Louis, M., Sugden, K., Wu, M (2012) Enterprise and equality: a study of Avon in S. Africa, Entrepreneurship Theory and Practice, May, DOI: 10.1111/j.1540-6520.2012.00507.x

Sevä, I.J. \& Öun, I. (2015). Self - Employment as a Strategy for Dealing with the Competing Demands of Work and Family? The Importance of Family/Lifestyle Motives. Gender, Work \& Organization, 22(3), 256-272.

Shabbir \& Di Gregorio (1996) An examination of the relationship between women's personal goals and structural factors influencing their decision to start a business: the case of Pakistan, Journal of Business Venturing, 11, 6, 507-529

Shane, S. and Venkataraman, S. (2000). The promise of entrepreneurship as a field of research. Academy of Management Review, 25(2), 217-226. 
Shinnar R.S., Giacomin, O. \& Janssen (2012). Entrepreneurial perceptions and intentions: the role of gender and culture. Entrepreneurship Theory and Practice, May, 465-493.

Silberzahn, R. and Menges, J. (2016). Reading the face of a leader: women with low facial masculinity are perceived as competitive. Academy of Management Discoveries, 2(3), 272289.

Smirnova, Y., Mustafina, A., \& Aldabekova, M. (2012). Doing business in Kazakhstan: what can we learn from Malaysian experience? Interdisciplinary Journal of Contemporary Research in Business, 4(4), 24-35.

Soares, R., Marquis, C., \& Lee, M. (2011). Gender and corporate social responsibility: it's a matter of sustainability. Catalyst Report, November.

Spisak, B.R., Dekker, P.H., Kruger, M., \& van Vugt, M. (2012). Warriors and peacekeepers: testing a biosocial implicit leadership hypothesis of intergroup relations using masculine and feminine faces. PLoS One, 7: e30399. DOI: 10.1371/journal.pone.0030399.

Stewart, R. (1982). A model for understanding managerial jobs and behaviour. The Academy of Management Review, 7, 7-13.

Strauss, A.L. (1987). Qualitative analysis for social scientists. Cambridge: Cambridge University Press.

Tatli, A., \& Özbilgin, M. (2012). An emic approach to intersectional study of diversity at work: a Bourdieuan framing. International Journal of Management Reviews, 14, 180-200.

Teal, E. J., Toxanova, A. N., \& Izzo, G. M. (2011). Entrepreneurial development in Kazakhstan: a review and update. Journal of International Business and Cultural Studies, 5(1), 1-10.

The World Bank (2013). Kazakhstan. Available at: http://www.worldbank.org/en/country/kazakhstan (accessed 20 October 2014).

Thomas, R. D. (2006). A general inductive approach for analyzing qualitative evaluation data. American Journal of Evaluation, 27(2), 237-246.

Thornberry, N. (2006). Lead like an entrepreneur. Blacklick, OH: McGrawHill.

Timmons, J. A. (1994). New Venture Creation: Entrepreneurship for the 21st Century (4th ed.). Burr Ridge, IL: Irwin Press. 
Tlaiss, H. (2013). Entrepreneurial motivations of women: evidence from the United Arab Emirates. International Small Business Journal, 1(1), 1-20.

Van Emmerik, H., Euwema, M. C., \& Wendt, H. (2008). Leadership behaviors around the world: the relative importance of gender versus cultural background. International Journal of Cross-Cultural Management, 8(3), 297-315.

van Engen, M. L., van der Leeden, R., \& Willemsen, T. M. (2001). Gender, context, and leadership styles: A field study. Journal of Occupational and Organizational Psychology, 74, 581-598.

Wee, L., \& Brooks, A. (2012). Negotiating gendered subjectivity in the enterprise culture: Metaphor and entrepreneurial discourses. Gender, Work \& Organization, 19(6), 573-591.

Werner, C. (2003). Between market and family: women traders on the New Silk Road. In G. Clark (Ed.). Gender in Economic Life. Lanham, MD: Altamira Press.

Wippermann, C. (2010). Women in Executive Positions: Barriers and Bridges. Sinus Sociovision, Germany: Federal Ministry for Family Affairs, Senior Citizens, Women and Youth.

Youssef-Morgan, C. M. \& Luthans, F. (2013). Positive leadership: meaning and application across cultures. Organisational Dynamics, 42(3), 198-208.

Zhu, W., Riggio, R. E., Avolio, B. J., \& Sosik, J. J. (2011). The effect of leadership on follower moral identity: does transformational/transactional style make a difference? Journal of Leadership \& Organizational Studies, 18(2), 150-163. 
Table 1: Interviewee profile

\begin{tabular}{|c|c|c|c|c|c|}
\hline Identifier & Age & $\begin{array}{l}\text { Level of } \\
\text { Education }\end{array}$ & Leadership role & $\begin{array}{l}\text { Experience in } \\
\text { Leadership } \\
\text { Role (years) }\end{array}$ & Industry \\
\hline $\begin{array}{l}\text { Participant } \\
\text { A }\end{array}$ & $\mathrm{N} / \mathrm{D}$ & Bachelor & $\begin{array}{l}\text { CEO/ } \\
\text { Founder }\end{array}$ & 15 & $\begin{array}{l}\text { Education } \\
\text { Services }\end{array}$ \\
\hline $\begin{array}{l}\text { Participant } \\
\text { B }\end{array}$ & $\mathrm{N} / \mathrm{D}$ & Bachelor & Director & 5 & $\begin{array}{l}\text { Education } \\
\text { Services }\end{array}$ \\
\hline $\begin{array}{l}\text { Participant } \\
\text { C }\end{array}$ & $\mathrm{N} / \mathrm{D}$ & Bachelor & General Manager & 3 & Medical Services \\
\hline $\begin{array}{l}\text { Participant } \\
\text { D }\end{array}$ & 49 & $\mathrm{PhD}$ & $\mathrm{CFO} /$ Founder & 14 & $\begin{array}{c}\text { Educational } \\
\text { Services }\end{array}$ \\
\hline $\begin{array}{l}\text { Participant } \\
\mathbf{E}\end{array}$ & 42 & $\mathrm{PhD}$ & $\mathrm{CEO} /$ Founder & 13 & Higher Education \\
\hline $\begin{array}{l}\text { Participant } \\
\text { F }\end{array}$ & $\mathrm{N} / \mathrm{D}$ & LLM & CEO/ Founder & 13 & $\begin{array}{c}\text { Sports } \\
\text { (International) }\end{array}$ \\
\hline $\begin{array}{l}\text { Participant } \\
\text { H }\end{array}$ & 35 & MA & Director & 5 & $\begin{array}{c}\text { Clothing } \\
\text { Manufacturing } \\
\text { and Retail Outlet }\end{array}$ \\
\hline $\begin{array}{l}\text { Participant } \\
\text { I }\end{array}$ & 57 & Bachelor & Director & 15 & Manufacturing \\
\hline $\begin{array}{l}\text { Participant } \\
\text { J }\end{array}$ & $\mathrm{N} / \mathrm{D}$ & MSc & Director & 4 & Medical Services \\
\hline $\begin{array}{l}\text { Participant } \\
\text { K }\end{array}$ & $\mathrm{N} / \mathrm{D}$ & MA & Director/ Founder & 12 & $\begin{array}{c}\text { Musical } \\
\text { Production }\end{array}$ \\
\hline $\begin{array}{l}\text { Participant } \\
\text { L }\end{array}$ & 52 & MA & CEO & 8 & Construction \\
\hline $\begin{array}{l}\text { Participant } \\
\mathbf{M}\end{array}$ & $\mathrm{N} / \mathrm{D}$ & MSc & $\begin{array}{l}\text { Head of regional } \\
\text { division }\end{array}$ & 7 & Finance \\
\hline $\begin{array}{l}\text { Participant } \\
\mathbf{N}\end{array}$ & $\mathrm{N} / \mathrm{D}$ & MBA & Executive Director & 3 & Finance \\
\hline $\begin{array}{l}\text { Participant } \\
\text { O }\end{array}$ & 32 & MA & CEO/ Founder & 6 & $\begin{array}{l}\text { Fashion and } \\
\text { clothing }\end{array}$ \\
\hline $\begin{array}{l}\text { Participant } \\
\mathbf{P}\end{array}$ & 36 & MSc & General Manager & 10 & Retail \\
\hline $\begin{array}{l}\text { Participant } \\
\mathbf{Q}\end{array}$ & $\mathrm{N} / \mathrm{D}$ & MA & Executive Director & 11.5 & Retail \\
\hline $\begin{array}{l}\text { Participant } \\
\mathbf{R}\end{array}$ & 33 & $\begin{array}{l}\text { MBA, } \\
\text { MA }\end{array}$ & $\begin{array}{l}\text { Director of } \\
\text { Department }\end{array}$ & 3 & Government \\
\hline $\begin{array}{l}\text { Participant } \\
\text { S }\end{array}$ & 36 & Bachelor & Executive Director & 6 & NGO \\
\hline
\end{tabular}


Table 2: Summary of findings

\begin{tabular}{|c|c|}
\hline Items & Descriptors \\
\hline Beliefs & $\begin{array}{l}\text { - Creation of value (profitability and well-being of stakeholders/society) } \\
\text { - Well-being/benefit for a wide range of stakeholders } \\
\text { - Collaboration }\end{array}$ \\
\hline Demands & $\begin{array}{l}\text { - Delivering results (financial and non-financial) } \\
\text { - Self-actualisation } \\
\text { - Resilience }\end{array}$ \\
\hline Constraints & $\begin{array}{l}\text { - Resource scarcity } \\
\text { - Lack of shared understanding } \\
\text { - Lack of mental models } \\
\text { - Rigid structures } \\
\text { - Commitments (business and family) }\end{array}$ \\
\hline Choice & $\begin{array}{l}\text { - Flexible behavioural stole } \\
\text { - Collaboration } \\
\text { - Career development } \\
\text { - Co-developmental options }\end{array}$ \\
\hline
\end{tabular}

